\title{
Becoming sedentary? The seasonality of food resource exploitation in the Mesolithic-Neolithic Danube Gorges
}

\author{
Vesna Dimitrijević 1 , Ivana Živaljević 2 and Sofija Stefanović 2 \\ 1 Laboratory for Bioarchaeology, Department of Archaeology, Faculty of Philosophy, University of Belgrade, RS \\ vdimitri@f.bg.ac.rs \\ 2 BioSense Institute, University of Novi Sad, RS \\ sofija.stefanovic@biosense.rs
}

\begin{abstract}
In this paper, we investigate whether the Mesolithic-Neolithic sites in the Danube Gorges were occupied seasonally or all year round by looking at animal skeletal remains. The hunting seasons of most important game animals have been determined on the basis of antler and teeth growth, supplemented by looking into the presence of migratory fish and birds. The patterns of food resource exploitation seem to indicate year-round occupation of the settlements, and suggest that a significant degree of sedentism existed in the Danube Gorges prior to, and independently of, the adoption of animal and plant husbandry.
\end{abstract}

IZVLEČEK - V članku na podlagi analize živalskih ostankov raziskujemo, ali so bila mezolitsko-neolitska najdišča na območju soteske Džerdap poseljena sezonsko ali čez celo leto. Na podlagi rasti rogovja in zob smo določili lovno sezono za najpomembnejšo divjad, podatke pa smo dopolnili z analizo selitve rib in ptic. Vzorci rabe raznih virov prehrane kažejo na celoletno poselitev na naselbinah; sklepamo tudi, da se je na območju Džerdapa delno sedentaren način življenja pojavil ločeno od in pred pojavom prvih domačih živali in kultiviranih rastlin.

KEY WORDS - seasonality; archaeozoology; sedentism; Danube Gorges; Mesolithic-Neolithic

\section{Introduction}

With their long temporal sequence, spanning between $c .9500$ to $5500 \mathrm{cal} \mathrm{BC}$ (corresponding to the regional Mesolithic, Mesolithic-Neolithic Transformation phase and the Early/Middle Neolithic) (Borić, Dimitrijevic 2009; Boric 2011), open-air sites in the Danube Gorges (North-Central Balkans) provide great opportunities for studying and understanding various aspects of Mesolithic-Neolithic transition. In particular, intensified building activities in the Late Mesolithic and Transformational Mesolithic-Neolithic phases (cf. Borić, Dimitrijević 2009; Borić 2011) have been interpreted as archaeological indicators of increased sedentism resulting from developing social complexity of local hunter-gatherer-fisher communities (cf. Voytek, Tringham 1989; Chapman 1993; Radovanović 1996; Radovanović, Voytek 1997) and from merging local traditions with new economic and social practices accompanying 'Neolithic' lifeways (cf. Borić 2007; 2011; Jovanović 2008). Obviously, there is no universal mode of hunter-fishergatherer existence, as opposed to a presumed sedentary lifestyle of food-producing communities, nor can a clear-cut change from mobility to sedentism be assumed. Moreover, degrees of sedentism are often difficult to assess and divide into neat categories due to the complexity of human lifestyles and residential practices (cf. Whittle 2001). One of the starting points, however, most commonly involves determining whether the sites in question were occupied seasonally or year-round. This feature can be addressed by looking at subsistence patterns, i.e. the seasons of exploitation of most important animal species, as has been demonstrated by a number of studies, which range from simple observations of the pres- 
ence/absence of seasonally available fauna, to more sophisticated analytical procedures, including the determination of the individual ages and the season of death of exploited animals, skeletochronology, or growth-increment studies (cf. Pike-Tay et al. 2004), or stable isotope balances in teeth and bones (Blaise, Balasse 2011).

In this study, we present estimated seasons of capture on the basis of the results of ageing of faunal skeletal elements (teeth and antler) of economically important wild game species, supplemented by quantifications of fish and bird remains (some of them available seasonally and others more or less all year round) from sites at Vlasac, Lepenski Vir, and Padina. By no means exhaustive, this study aims to offer additional data relevant to understanding subsistence and settlement patterns, and to shed more light on the relationship between hunting, fishing and increased sedentism in the Danube Gorges.

\section{Archaeological background}

The Padina, Lepenski Vir, and Vlasac sites are situated in the Upper Gorge (Gospodin Vir, or Lady's Whirlpool) of the Danube Gorges (Fig. 1), on riverine terraces sloping towards the Danube. The initial rescue excavations of the sites were undertaken in the 1960s and 1970s (Srejovic 1969; 1972; Srejović, Letica 1978; Radovanović 1996; Jovanović 2008 ), prior to the raising of the water level due to dam construction, and new revisory excavations of the preserved portion of the Vlasac terrace were carried out in 2006-2009 (Borić 2006; Borić et al. $2008 ; 2014)$. The earliest traces of human presence in these locations date to the period of $c$. 95007400 cal BC (the Early Mesolithic) (Boric, Dimitrijević 2009; Borić 2011), and are manifested by occasional burials (some in a seated position), several stone constructions (Borić, Miracle 2004; Jovanović
2008), as well as caches of animal bones originating predominantly from wild game and fish (Boric, $D i$ mitrijević 2006), but also from canids displaying mixed wolf and dog features, suggesting that the initial stages of dog domestication took place during this time (Dimitrijević, Vuković 2015).

The few and fragmentary traces of Early Mesolithic occupation are mostly due to their disturbance and devastation by later (Late Mesolithic and Transformation phase) building and occupational activities (Boric 2011). The Late Mesolithic phase (c. 7400$6300 / 6200$ cal BC) is particularly well documented at Vlasac (Borić 2011), where numerous burials, several dug-out dwelling structures, stone-lined rectangular hearths and a large number of chipped stone, bone and antler artefacts have been discovered (Srejović, Letica 1978; Nemeskéri 1978; Kozłowski, Kozłowski 1982; Roksandić 1999; 2000; Borić et al. 2008; 2014), as well as an enormous assemblage of animal bones (Bökönyi 1978). This phase also produced evidence of large-scale exchange networks, witnessed by occasional finds of good-quality flint of non-local origin, and the occurrence of marine gastropods Cyclope neritea and Columbella rustica in some of the burials (Cristiani, Boric 2012; Borić et al. 2014; Srejović, Letica 1978).

The Transformation/Early Neolithic phase (c. 6300/ 6200-5900 cal BC) (Borić, Dimitrijević 2007; Borić 2011), coinciding with the emergence of the first farming communities in the Balkans, saw the establishment of the first settlements with elaborate trapezoidal-base dwellings, distinctive sandstone sculpted boulders and the introduction of pottery at Lepenski Vir and Padina (Srejović 1969; 1972; Radovanović 1996; Garašanin, Radovanović 2001; Jovanović 2008), but with unchanged subsistence strategies dependent on hunting and fishing (Boric, $D i$ mitrijevic 2006). The first domesticates (apart from

Fig. 1. The Danube Gorges area with relevant sites mentioned in the text. The position of the Danube Gorges within a wider area - the Balkan peninsula shown in the lower left corner. Images from Google Earth.

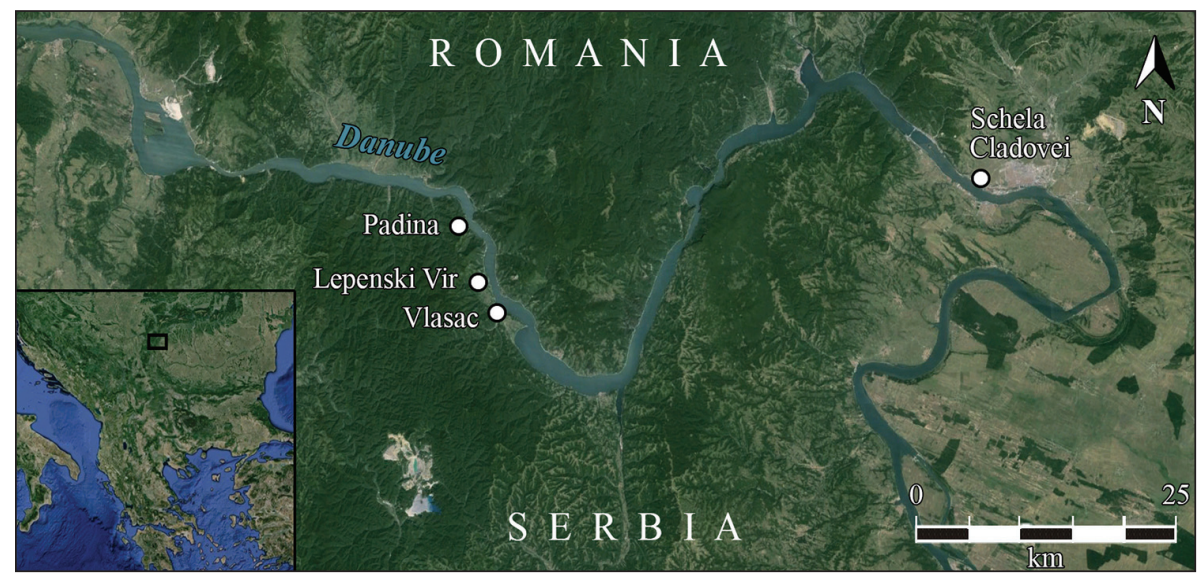


dogs) make an appearance only after $c .6000 / 5900$ cal BC (Borić, Dimitrijević 2007), after most of the dwellings had been abandoned and new elements of material culture (domed ovens, ground stone tools, bone spoons), along with certain individuals of nonlocal origin appear in the area (Boric 2011; Boric, Price 2013). Large-scale animal husbandry, however, was never fully introduced into the Upper Gorge; the sites continued to be in use until $c .5500 \mathrm{cal} \mathrm{BC}$, but probably for specialised activities, most notably fishing (Bonsall 2008; Borić 2011).

\section{The faunal assemblages}

The assessment of the nature of animal exploitation and quantification of faunal remains from the Danube Gorges are hindered by several factors, namely the inadequate recovery techniques and selective collection imposed by time constraints during the course of the excavations, and the fragmentary state of faunal assemblages from some of the sites (Boric 2001; 2002; Borić, Dimitrijević 2006; Dimitrijević 2000; 2008). The faunal assemblages from the old excavations of Lepenski Vir (1965-1970), Vlasac (19701971), and Padina (1968-1970) were collected entirely by hand, using collection grids consisting of $4 x 4 m$ quadrants. Furthermore, the enormous assemblage from the original excavations of Vlasac, comprising nearly 30000 identified specimens was discarded after the initial analysis by Sándor Bökönyi (1978), with only a small sample of bird (Tab. 5) and fish remains preserved (Boric 2002.App. 5; Dimitrijevic et al. submitted). Part of the faunal assemblage from Lepenski Vir, mainly from first excavation seasons (up to 1969, cf. Borić, Dimitrijević 2006) was also discarded after the preliminary analysis by Bökönyi (1969; 1970; 1972). The preserved part of the assemblage originated from later campaigns (1968-1970), and consisted of animal bones primarily related to the floors of trapezoidal-base dwellings, and areas between and underneath them (Dimitrijevic 2000; 2008). Only the faunal assemblage from the new (2006-2009) excavations of Vlasac, as well as the one collected in 1992-1996 at the downstream site of Schela Cladovei (Fig. 1) (Bartosiewicz et al. 1995; 2001; 2008), were collected by water sieving and flotation, in addition to hand collection (Borić et al. 2014; Dimitrijević et al. submitted).

The environment of Padina, Lepenski Vir and Vlasac, which were situated on riverine terraces in a narrow belt between the river and the forest, provided both good hunting and fishing conditions. The dense forests surrounding the sites were the natur- al habitat of various wild game species which were hunted for meat, as well fur-bearing animals which were probably hunted for fur or as vermin. The vicinity of the river and its large whirlpools enabled fishing for both freshwater species (available most of the year) and seasonally available anadromous species, as well as the exploitation of waterfowl.

In terms of wild game at all three sites, the most numerous remains are of red deer (Cervus elaphus) which was most commonly hunted, followed by wild boar (Sus scrofa), roe deer (Capreolus capreolus), and aurochs (Bos primigenius) (cf. Bökönyi 1969; 1970; 1972; 1978; Clason 1980; Dimitrijević 2008). In terms of fishes, the remains of various cyprinids (Cyprinidae), Wels catfish (Silurus glanis), migratory sturgeons (Acipenseridae), and huchen (Hucho hucho) have been discovered at all three sites, but in varying quantities (Živaljević in prep.). As expected, the hand-collected, water-sieved and flotated sample from new excavations of Vlasac contained many more remains of smaller cyprinids and exhibited the greatest species diversity in comparison to hand-collected assemblages from Lepenski Vir and Padina (Tab. 4). However, in spite of the same collection methods employed at the latter two sites, their faunal assemblages also exhibited significant differences, namely in the absolute predominance of catfish observed at Padina. The Lepenski Vir assemblage contained a significant number of cyprinid, catfish and huchen remains, but also a much greater number of sturgeon remains in comparison to $\mathrm{Pa}$ dina and Vlasac (Tab. 4).

The role of hunting $v s$. fishing in subsistence strategies is difficult to assess on the basis of a straightforward comparison of quantified mammal and fish remains, given the differences in their anatomy and size, and biases affecting their survival and recovery (cf. Wheeler, Jones 1989; Takács, Bartosiewicz 1998; Bartosiewicz, Bonsall 2004; Borić 2001). The analyses of carbon $\left(\delta^{13 \mathrm{C}}\right)$ and nitrogen $(\delta 15 \mathrm{~N})$ isotope ratios in human bone collagen have suggested that the Mesolithic inhabitants of the Danube Gorges consumed considerable amounts of fish, with a gradual broadening of the dietary spectrum to include more terrestrial resources at the onset of the Neolithic (Bonsall et al. 1997; 2004; Grupe et al. 2003; Boric et al. 2004), whereas the analysis of the sulphur $\left(\delta^{34} \mathrm{~S}\right)$ isotope ratio has suggested that there have been significant inter- and intra-site variabilities in dietary practices (Nehlich et al. 2010). On the basis of faunal data, it can be hypothesised that both hunting and fishing made significant contribu- 
tions to the diet; the former mainly oriented towards red deer and the latter exhibiting more intrasite (and possibly diachronic) variety.

Apart from a general emphasis on the importance of annual cycles in shaping human lives in the Danube Gorges (cf. Srejovic 1969; 1972), the subject of seasonality was first addressed by Anneke T. Clason (1980) in her study of Starčevo and Padina animal remains. In the description of mammal remains, she specified some specimens as seasonal markers, made some remarks on the seasonal availability of bird and fish, and hypothesised that "Padina was permanently inhabited during all seasons of the year", and furthermore, that this was probably also true for Vlasac and Lepenski Vir. A discussion on the influences of seasonal cycles on life in the Mesolithic Danube Gorges is given by Borić in his thesis (BOric 2002). Here, and in several later references, seasonal estimates determined on the basis of particular specimens of mammal remains were also noted (Dimitrijević 2000; 2008; Borić, Dimitrijević 2006; 2009).

\section{Materials and methods}

The seasonal schedule of food resource acquisition in the Danube Gorges has been determined on the basis of skeletal elements which are sensitive to the question of seasonality. This included determining the kill season of red deer and roe deer on the basis of antler growth (cf. Schmid 1972), and ageing of red deer, roe deer, fox and wild boar on the basis of tooth eruption and wear (cf. Habermehl 1985; Brown, Chapman 1991; Carter 2006; Carter, Magnell 2007) (Tabs. 1-3). Although radiographs were not made, the fragmentary state of some of the mandibles and loose teeth enabled ageing on the basis of root formation stages (after Brown, Chapman 1991; Carter 2006; Carter, Magnell 2007). Other mammal species were not taken into account, either because they were not represented by juvenile animals, are not seasonal breeders, or they give birth several times a year. The breeding and reproduction patterns of dogs in particular could have changed significantly as a result of domestication, and could have extended throughout several seasons.

In this respect, the most reliable season indicators are milk and erupting permanent teeth of juvenile animals, given that they follow a fairly standardised schedule, whereas tooth wear does not occur at an even pace (Bartosiewicz 1989; Pike-Tay et al. 2004). Less reliable season indicators are shed antlers; even if they are dropped during limited periods of the year (February-March in the case of red deer and October-November for roe deer, cf. Schmid 1972), they could have been collected at any time and/or curated, especially since they were extremely valued as raw material and often structurally deposited.

We assumed that red deer give birth at the beginning of June (cf. Carter 2006); similarly, the birthing season of recent red deer populations in the region is described as taking place "at the end of May - beginning of June" (Grupa autora 1991). Roe deer give birth in May (Grupa autora 1991; Habermehl 1985; Carter 2006). The farrowing season of wild swine is seasonally less restricted, occuring in March-April in recent wild pig populations in the Balkans (Grupa autora 1991), whereas in Sweden and Germany (Carter, Magnell 2007), as well as in Turkey (Bull, Payne 1982) it occurs between March and May. Wild sows may breed twice a year, thus substantially widening the farrowing season; however, $65-90 \%$ of births occur between March and May, mostly March and April in Sweden and Germany (Carter, Magnell 2007 and references therein). Similarly, in the Balkans, $85 \%$ of births take place in March and April (Grupa autora 1991). Fox cubs are born in March (Habermehl 1985).

The observations on the hunting seasons of most important game animals were supplemented by looking into the seasonal availability of migratory fish and birds and quantifying their remains (Tabs. 4-5). As noted by László Bartosiewicz and Clive Bonsall (2004) and Bartosiewicz et alii (2008), the presence/absence criteria is highly probabilistic, given that the presence of a certain species might signal occupation during a particular season, but its absence does not imply the lack of occupation at other times. For example, prior to the Iron Gates' dams construction, anadromous sturgeons - beluga (Huso huso), Russian sturgeon (Acipenser gueldenstaedtii), ship sturgeon (Acipenser nudiventris), and stellate sturgeon (Acipenser stellatus), undertook their bi-annual spawning migrations from the Black Sea at particular times of the year (in early spring and autumn), but with inter-specific and individual differences in the start and peak dates depending on water temperature. Also, the populations migrating in autumn were known to overwinter in the river (Ristic 1977). It should be noted, however, that the main sturgeon fishing seasons in the Danube Gorges in more recent times corresponded with their migration patterns, with most catches occurring in spring, followed by autumn (cf. Petrović 1998. [1941]; for 
different data from Hungary, see Bartosiewicz et al. 2008).

The investigation of the presence of migratory birds as seasonal indicators is also based on the assumption that their behaviour in the past roughly mirrored their present migration patterns. In addition, it should be noted that bird remains at sites could have been accumulated not only by humans and dogs, but wild predators as well, having in mind that no bird bones bore butchering marks. This hypothesis does not seem likely for certain species - particularly birds of prey, which nested in the high cliffs of the Gorges - but cannot be completely ruled out.

Therefore, the data we present here includes the suggested seasons of kill of the most important game animals, which could vary to some extent due to slight or greater variations in the birthing seasons of the species and their ontogeny, as well as the most probable seasons of exploitation of migratory species, assuming their past migration patterns broadly correspond to those observable in more recent times.

\section{Results}

\section{Vlasac}

As opposed to the $640 \mathrm{~m}^{2}$ area excavated in 1970 1971 (Srejović, Letica 1978), the preserved portion of the Vlasac terrace encompassed by the 20062009 excavations $\left(326 \mathrm{~m}^{2}\right)$ covered the southernmost peripheral area of the original settlement $(B O-$ rić et al. 2014), with much less evidence of domestic activities or food preparation and consumption (Dimitrijević et al. submitted). This feature is certainly manifested in the quantity and preservation of animal remains from the two areas of the site, in particular concerning mammal remains, which are least likely to suffer from bias in recovery techniques. The total number of mammal bone specimens identified to the species/genus/family level from the 1970-1971 excavations equaled 11188 (Bökönyi 1978), as opposed to 801 specimen identified to the species/genus/family level and 10955 unidentified mammal remains from the 2006-2009 excavations (Dimitrijevic et al. submitted). In terms of the most important game animals, the NISP (number of identified specimens) of red deer, wild boar and roe deer in the 1970-1971 assemblage equaled 6732, 1185 and 510, respectively (Bökönyi 1978), as opposed to their NISP in the 2006-2009 assemblage (209, 86 and 47, respectively) (Dimitrijević et al. submitted). However, due to more sophisticated collection techniques, the new excavations of Vlasac enabled the recovery of even the most fragile skeletal elements, including the deciduous teeth which were used in this study (Tab. 1), as well as a plentitude of fish remains (Tab. 4).

Most of the mammal remains used in this study originated from the 2006-2009 excavations of Vlasac, and included a fragmented red deer skull, a fragment of a roe deer skull with an antler, as well as deciduous and permanent teeth of red deer, roe deer, wild boar and fox. Given that the largest part of the faunal assemblage from 1970-1971 was discarded, in this study we were able to include only 9 unshed and 31 shed antlers of red deer, and 3 unshed antlers of roe deer, which were originally packed with bone and antler artefacts and thus saved (Tab. 1).

The fragmented red deer skull VL 29/1 (Fig. 2) originated from a young male, and on the basis of partially preserved antlers still on pedicles, it was determined that it was captured between September and February. The skull had been used (possibly, for a significant amount of time), most likely in a series of ritualistic activities, given that it exhibited a number of modifications (numerous cuts and damage to the cranial roof and flattened occipital condyles) which could not be explained by standard butchering practices (Dimitrijevic et al. submitted), and that it had been deposited at the top of a sequence of several inhumations and cremations (Borić 2010; Boric et al. 2014.Tab. 1: the skull is described as originating from context 19). Unshed antlers collected over the course of previous excavations indicate the same broad (autumn-winter) time span, whereas, as

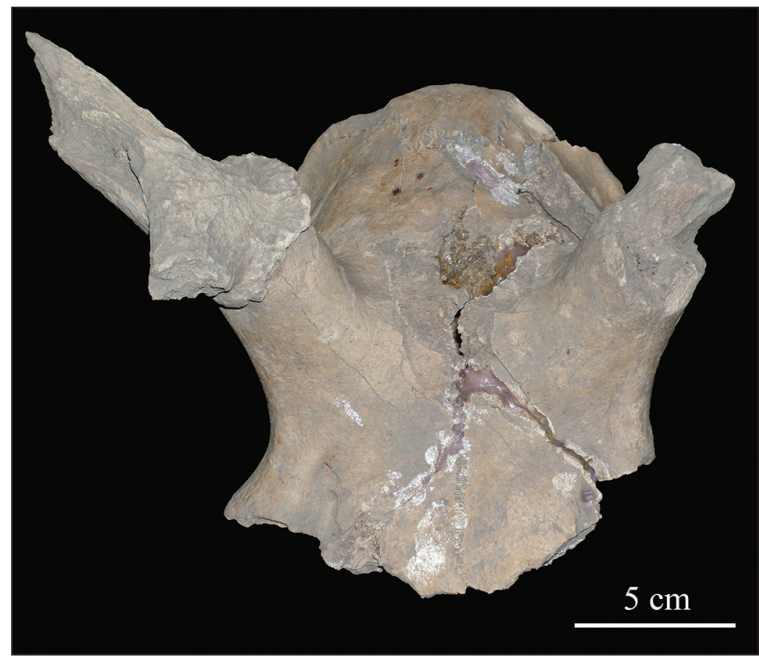

Fig. 2. Fragmented male red deer skull (VL 29/1) from Vlasac, with fragmented antlers attached to pedicles, captured between September and February. 
already noted, the use of shed antlers (even though shedding occures within a short time span) as seasonal indicators should be taken with caution, as it is possible they were collected later.

The stages of teeth eruption and wear indicate several seasons of capture of red deer, some with more precision than others. In particular, a $3^{\text {rd }}$ and $4^{\text {th }}$ decidious premolar from a fragmented left maxilla (VL 216/15) (Fig. 3) pointed to an age of 7-8 months, indicative of a December-January capture; whereas a left $3^{\text {rd }}$ permanent incisor with an open root and milk incisors (left and right $2^{\text {nd }}$ and $3^{\text {rd }}$ ) and right canine (VL 237/4) (Fig. 4) from a mandible that had not been preserved pointed to an approximat eage of 15-18 months or a kill that occurred between August and November.

A fragment of a roe deer skull with an antler fragment on a pedicle (VL $314 \mathrm{x}$. 23), as well as three unshed antlers collected in previous excavations indicated that the capture seasons occurred between May and October (cf. Schmidt 1972). Assuming the end of May as the season when roe deer give birth (cf. Habermehl 1985), one decidious premolar (3/4) (VL 51/1) indicated an age of one month, i.e. a June capture.

As already noted, the farrowing season for wild swine is generally from March to April (cf. Grupa autora 1991; Carter, Magnell 2007); in our study, the ageing and the estimation of season is given counting from April (Tab. 1). Two teeth - an upper $3^{\text {rd }}$ deciduous premolar (VL 237/5) and an upper $2^{\text {nd }}$ deciduous premolar (VL 282/3) - produced fairly reliable season estimates, an April-May and SeptemberOctober kill respectively.

Fox teeth (an upper deciduous canine and a germ of the first molar, VL 222/22-23) were included in this study, as they provided a fairly reliable kill season
(May), given that this stage of teeth eruption is indicative of a three-month-old individual ( $c f$. Habermehl 1985).

Although most of the elements utilised in ageing offered very broad season estimates spanning over several months (Tab. 1), the aforementioned specimens provided fairly accurate and short seasons of death. They signal particular events which took place in December-January, April-May, May, June and September-October, i.e. are indicative that hunting did not take place during a limited period of the year. Both the fragment of a roe deer skull with an antler (VL 314 x. 23) and the red deer skull (VL 29/1) have been directly dated, producing a date of 7131-6823 cal BC at 95\% probability (OxA-21962) and 60065838 cal BC at $95 \%$ probability (0xA-16544) respectively (Borić et al. 2014). At the same time, these two dates are currently the oldest and the youngest obtained from the new excavations of Vlasac, thus dating the span of activities in the peripheral zone of the settlement, with Transformation phase activity (post $c .6200 \mathrm{cal} \mathrm{BC}$ ) mainly related to the interment of the latest burials in the successive burial zone closed by the red deer skull (Boric et al. 2008; 2014 ). A wild boar tooth (VL 282/3) was found in a context (a concentration of artefacts beneath the floor of a dug-out dwelling) dated with two absolute dates: 7034-6692 cal BC at 95\% probability (0xA$24809)$ and $7035-6698 \mathrm{cal} \mathrm{BC}$ at $95 \%$ probability (0xA-24810) (Borić et al. 2014). From the previous 1970-1971 excavations, encompassing the central area of the settlement, a roe deer skull with antlers found on the floor of Building 2 (Srejovic, Letica 1978 ) produced a date of $7047-6699 \mathrm{cal} \mathrm{BC}$ at $95 \%$ probability (0xA-16216) (Borić et al. 2008). Therefore, it can be concluded that the majority of these events occurred during the last century of the $8^{\text {th }}$ millennium and the first half of 7 th millennium BC, and could be taken as representative of Late Mesolithic resource exploitation patterns at the site.

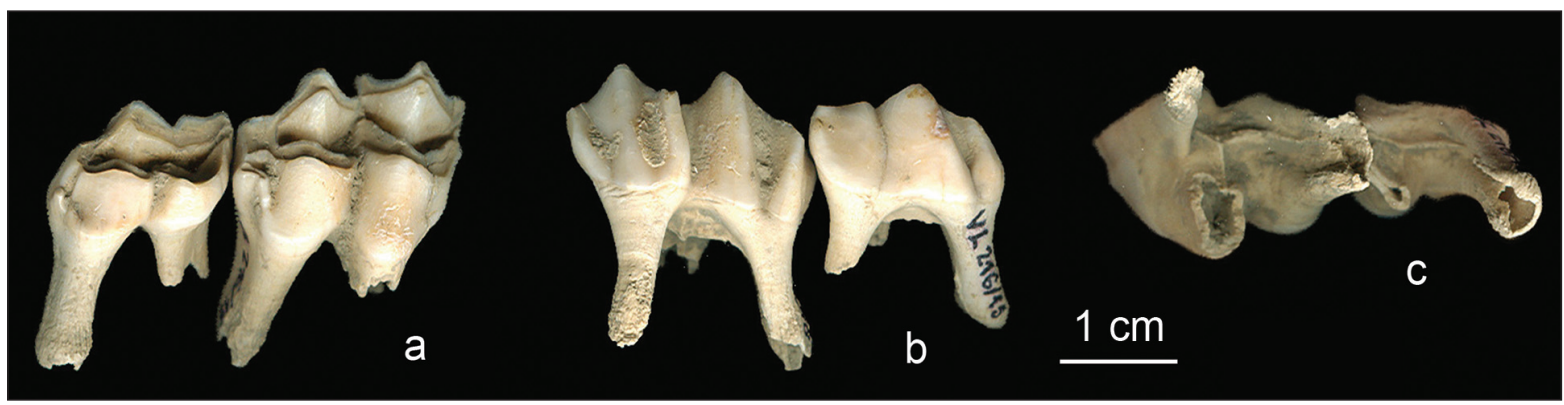

Fig. 3. $3^{\text {rd }}$ and $4^{\text {th }}$ decidious premolar from a fragmented red deer left maxilla (VL 216/15) from Vlasac, indicating an age of 7-8 months or a December-January capture: a lingual view; b buccal view; c roots, apical view. 


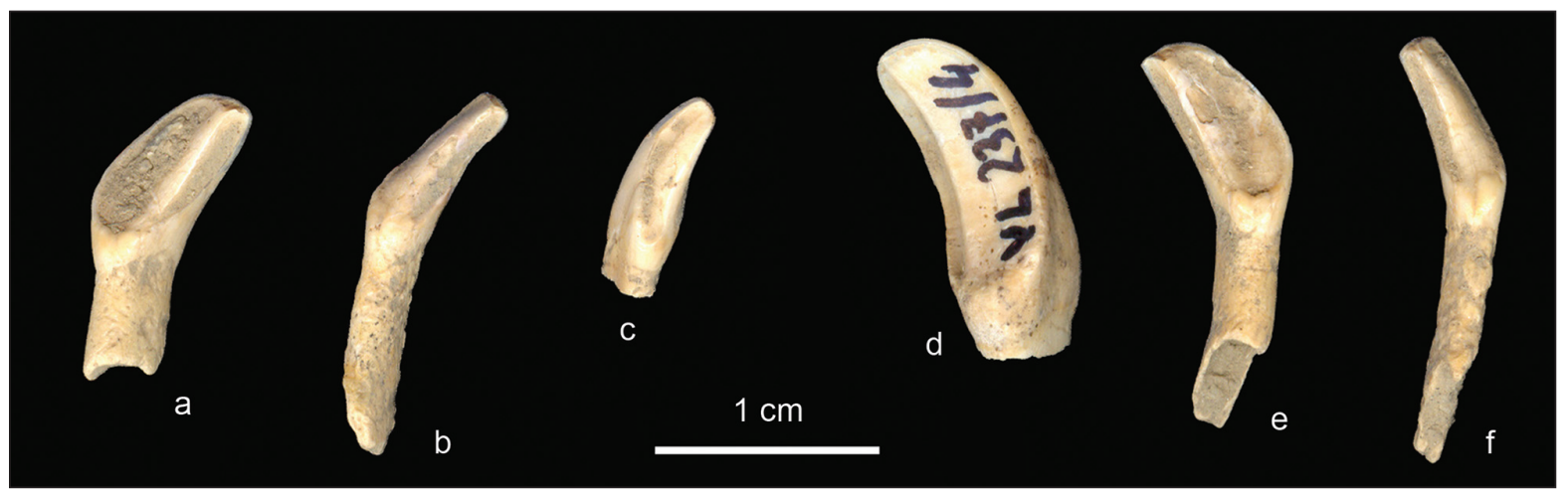

Fig. 4. Red deer permanent and milk front teeth (VL 237/4) from a mandible that had not been preserved from Vlasac, indicating an age of 15-18 months or an August-November kill: a right milk 2nd incisor; b right milk $3^{\text {rd }}$ incisor; c right milk canine; d a germ of the left $3^{\text {rd }}$ permanent incisor; e left $2^{\text {nd }}$ milk incisor; f left $3^{\text {rd }}$ milk incisor.

Similarly to mammal remains, the fish faunal assemblage from 2006-2009 displayed significant differences in comparison to the one collected in 19701971. Only common carp (Cyprinus carpio), catfish, pike (Esox lucius), unidentified cyprinids and a great number of unidentified fish bones were reported by Bökönyi (1978). The absence of sturgeon was clearly a result of author-related bias, given that sturgeon remains were in fact identified in the preserved faunal sample from 1970-1971 (Borić 2002.App. 5), as well as in the sample from new excavations of Vlasac (Živaljević in prep.) (Tab. 4). Albeit few, the remains of migratory beluga, Russian sturgeon and stellate sturgeon are indicative of spring and autumn fishing at the site, given that sturgeon remains as a rule tend to be underrepresented due to their largely cartilaginous skeleton (Brinkhuizen 1986; Bartosiewicz et al. 2008). The exploitation of anadromous Black Sea shad (Alosa immaculata) would have been even more seasonally restricted, as the species is present in the Danube only between the end of March and the beginning of June (Tab. 4). However, the vast majority of fish remains from the new excavations of Vlasac originated from yet another anadromous species - the vyrezub (Rutilus frisii) of the cyprinid family, mainly due to the large number of its pharyngeal teeth found in burials, but also in 'loose' contexts. Burials with pharyngeal teeth ornaments, from both the old and new excavations of Vlasac have mainly been related to the Late Mesolithic phase, but have also been found in a Transformation phase burial at Vlasac and settlement deposits at Lepenski Vir (Cristiani, Borić 2012; Cristiani et al. 2014; Borić et al. 2014; Živaljević in prep.), whereas unmodified vyrezub teeth and bones occur as early as mid-10th millenium BC (Early Mesolithic) at Lepenski Vir (Živaljević in prep.). The species has not been reported in the Middle/Lower
Danube previously, but it was probably migrating into the river from the Black Sea at least up to the Middle Holocene (Živaljevic et al. submitted). Modern Black Sea populations enter the rivers in October, overwinter in freshwater, and return to estuaries after spawning, which takes place in April and May (Kottelat, Freyhof 2007). Therefore, it can be hypothesised that the main fishing seasons at Vlasac corresponded with their autumn migration and spring spawning season, although the possibilities of winter catches should not be excluded. The possibility of opportunistic winter exploitation of freshwater fish should also be allowed, although fishing during this time would have been difficult, as most species take refuge on the river bottom and hibernate until spring. The remains of pike, one of the few species most succesfully caught from January to April (Tab. 4), could be indicative of winter fishing at Vlasac.

The bird faunal assemblage from both new and old excavations of Vlasac contained the remains of aquatic birds and waterfowl, as well as birds of prey and songbirds. Given that bird remains were few even in the hand-collected, water-sieved and flotated sample from the new excavations (Tab. 5), it may be hypothesised that their exploitation was opportunistic. A somewhat greater frequency of imperial eagle (Aquila heliaca) and white-tailed eagle (Haliaeëtus albicilla) remains (Bökönyi 1978; Dimitrijević et al. submitted), and the spatial clustering of some of their remains around the area of Late Mesolithic Building 2 (Boric 2002.190) could suggest that these birds of prey were possibly held in special regard. Most of the species represented in the 1970-1971 and 2006-2009 assemblage are still resident in the Danube Gorges, and therefore their presence cannot be used as a seasonal indicator. The only exceptions 
include the remains of white pelican (Pelecanus $c f$. onocrotalus) which migrates to the area in OctoberNovember, black kite (Milvus migrans) and imperial eagle which are passage visitors, present from spring to autumn, and fieldfare (Turdus pilaris) which overwinters in the area (from November to March) (Tab. 5). In the case of the resident cormorant (Phalacrocorax carbo), teal (Anas crecca), and mallard (Anas platyrhynchos), it should be noted that their populations increase in winter, joined by visitors from Northwestern Europe ( $c f . R a$ šajski, Kiss 2004; Clason 1980.164). According to Anne Pike-Tay et alii (2004), teal and mallard are migratory, and are present in neighbouring Hungary in early spring and in autumn (the former used to breed in Hungary), whereas the great white egret (Egretta alba) and ferruginous duck (Aythya nyro$\mathrm{Ca}$ ) leave the area in winter. The data on present populations in Serbia and the Danube Gorges ( $R a \check{a} a j$ ski, Kiss 2004; Grubač et al. 2013) suggest that these are resident species, so their past migratory status is less clear.

\section{Lepenski Vir}

The hand-collected and partially preserved faunal assemblage from Lepenski Vir contained fewer elements sensitive to seasonality (Tab. 2), but their contextual provenance enables a better understanding of the use of trapezoidal-base dwellings and the site as a whole. At least 13 buildings contained red deer skulls with antlers (Bökönyi 1969; 1970; 1972), which were probably deposited on the floors, marking the event of house abandonment (Dimitrijevic 2000; 2008). Similarly to the structurally deposited red deer skull from Vlasac, these could have been curated over longer periods of time, but in a couple of cases provided a fairly reliable indication of the kill season.

One such example comes from House 28 in the westernmost (upstream) periphery of the settlement, where a red deer skull with unshed antlers (very thin and quite unusual in their asymmetry) had been deposited on the floor (Dimitrijevic 2000.Fig. 16; 2008.Fig. 7). The skull has been directly dated to a range $6206-5989$ cal BC at $95 \%$ probability (0xA-16078), which corresponds with the construction and use of the trapezoidal buildings, i.e. the phase identified as the Mesolithic-Neolithic Transformation (Boric, Dimitrijevic 2009). The skull was damaged during excavation, with only the antlers and frontal, temporal and occipital parts of the skull and the upper jaws remaining (Dimitrijevic 2000. Fig. 17), while fish and gastropod remains were stuck to the crushed skull bones. The age of the animal has been determined fairly accurately on the basis of its upper teeth, which were in the last stages of decidious/ permanent dentition replacement. In both right and left maxilla (LV 273/4), $3^{\text {rd }}$ decidious molars were still holding above the crowns of permanent fourth premolars, and it would have been a matter of days before they fell out. The $2^{\text {nd }}$ and $3^{\text {rd }}$ premolars, and the left $3^{\text {rd }}$ molar were erupting. This stage of dental development is related to an age of 27 months, which would signal that this individual was caught in October (Dimitrijevic 2000; 2008; cf. Brown, Chapman 1991).

Another example is a red deer skull (LV 261/1-2) deposited on the floor of House 22 (Dimitrijevic 2008. Fig. 3). At present, only antlers have been preserved, one of which produced a date of 6084-5926 cal BC at 95\% probability (0xA-16075) (Borić, Dimitrijevic 2009), but both the skull (placed upside down) and antlers can be seen in a photograph taken during excavation (Fig. 5). The animal was just about to shed its antlers at the moment of capture; as a result, they parted from the skull when excavated. This occurrence is a fairly reliable indicator that the kill took place in February-March, and the deposition of the skull shortly after. Given that the abandonment of aforementioned House 28 was marked by a red deer skull from an individual caught in October, these two instances indicate that the 'life cycles' of each building were probably unique, ending with similar preparations but at different times throughout the year. It would seem that certain buildings were in use after others fell into disuse; this practice is also suggested by the deposition of sculpted boulders. Most boulders were initially placed in the rear area of rectangular hearths; however, certain dwellings had empty sockets in the floor behind the hearth area, or merely a fragment of an originally larger boulder inserted in the socket, which suggests that some of the boulders were moved from abandoned buildings and inserted at new locations (Srejovic 1969; Boric 2005). Consequently, the data on seasons of abandonment enables a better understanding of the individual histories of the houses and the occupation of the settlement as a whole.

Another fairly accurate season indicator comes from a context underneath of the floor of House 31, where a cache of animal bones, including a large part of a red deer and a brown bear skeleton, as well as remains of chamois, wild boar, beluga, Russian sturgeon, common carp, vyrezub, catfish, huchen and an unidentified bird bone have been found (Dimitrije- 


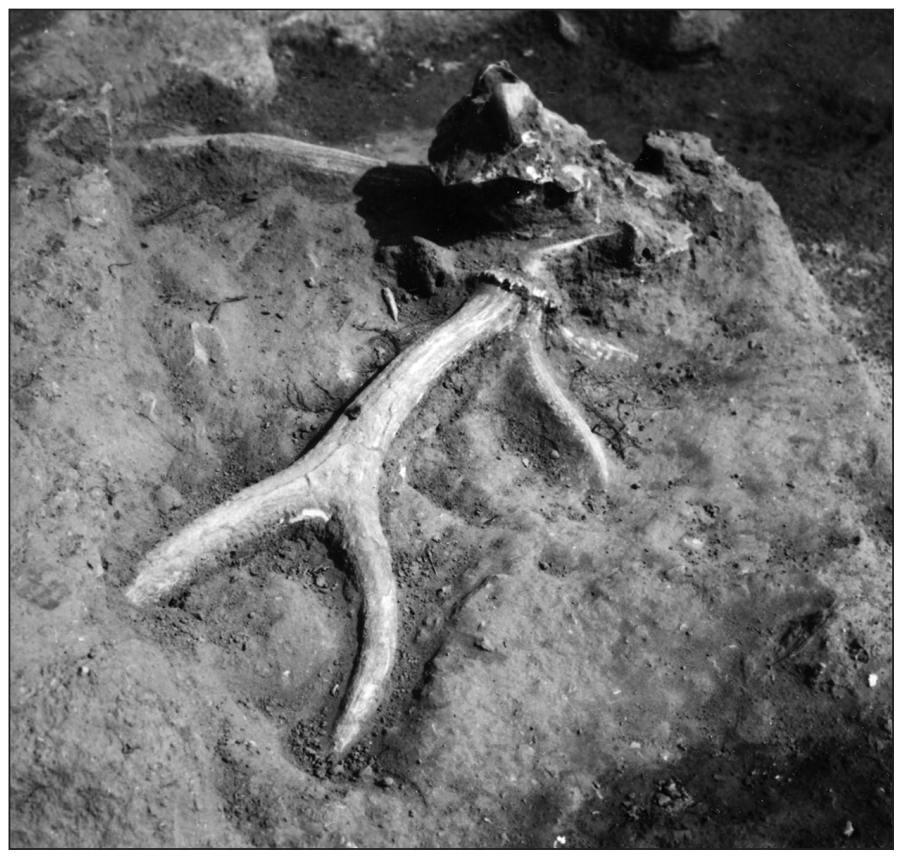

Fig. 5. Red deer skull with antlers (LV 261/1-2) deposited facing the floor of House 22 at Lepenski Vir; the kill took place in February-March. Photo from the archive of the Computer Documentation Centre, Faculty of Philosophy, Belgrade. ber (Dimitrijević 2000; cf. Brown, Chapman 1991; Carter 2006). If we assume that the whole faunal assemblage underneath House 31 accumulated over a short period, September would correspond with the start of the autumn migration of beluga and Russian sturgeon (Tab. 4), slightly preceding the start of vyrezub migration, if migratory patterns of modern populations are taken into account.

Another red deer mandible (LV bb-14/3) (Fig. 6) from an unspecified context originated from a 13- to 15-month-old individual, judging from the presence of $2^{\text {nd }}, 3^{\text {rd }}$ and $4^{\text {th }}$ decidious molars with formed but unresorbed roots (cf. Brown, Chapman 1991). This specimen is indicative of a summer kill event that took place between July and September.

An autumn/winter kill is suggested in the case of a red deer left maxilla (LV 1074/5) found in the eastern part of the settlement vić 2000; Borić, Dimitrijević 2006; Živaljević in prep.). The context has not been AMS dated, but given that the deposition of faunal remains predated the house construction, it can be concluded that the event(s) took place during an early settlement phase. The unity of the assemblage is seen in the large portions of the red deer and brown bear carcasses, which were probably butchered in situ. The red deer remains originated from a young individual, given its milk dentition, unfused proximal and distal epiphyses of long bones and porous structure of the short bones. Its age has been determined on the basis of a left mandible (LV bb-30/2) with a $2^{\text {nd }}$ and $3^{\text {rd }}$ decidious molar, alveole for the $4^{\text {th }}$ decidious molar and an erupting 1 st permanent molar $(D i$ mitrijević 2000.Fig. 12). This stage of dental development and wear indicate a four-month-old individual, suggesting that the kill season was in Septem- (sq. a/11-14). The presence of both decidious $4^{\text {th }}$ molar and the $1^{\text {st }}$ permanent molar indicates a 12to 16-month-old individual (cf. Habermehl 1985), captured between October and February. The same season has been determined in the case of red deer maxillae (LV 1296/1) found beneath the floor of House 19. Both left and right maxilla had mixed decidious/permanent dentition (D4, M1; and D3-D4, M1, respectively) (Fig. 7), suggesting they also originated from a 12- to 16-month-old individual ( $c f$. Habermehl 1985). In addition, vyrezub pharyngeal teeth were stuck to the right maxilla. The OctoberFebruary time span corresponds well with the season during which vyrezub migrate to rivers and overwinters, but precedes its spawning season (Tab. 4).

The red deer maxilla with vyrezub teeth, as well as the aforementioned red deer skull from House 28

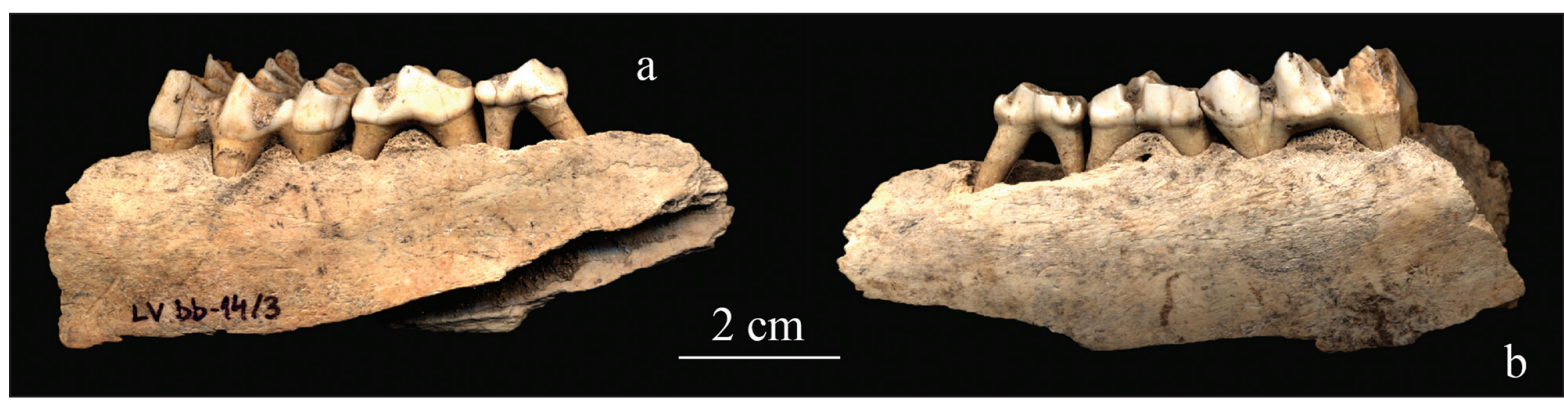

Fig. 6. Red deer right mandible with milk molars (LV bb-14/3) from Lepenski Vir, originating from a 1315 month old individual, killed between July and September: a buccal; b lingual. 
with small fish bones stuck to it seem to embody quite literally the merging role of wild game and fish. The fish faunal assemblage from Lepenski Vir consisted mainly of cyprinid remains (of freshwater species and anadromous vyrezub), as well as catfish, huchen and a small number of Black Sea shad, pike and pikeperch (Sander lucioperca) bones, but also a significant amount of remains of migratory sturgeon. Having in mind their largely cartilaginous skeleton and preservation bias affecting their remains (Brinkhuizen 1986; Bartosiewicz et al. 2008), it is remarkable that sturgeon constitute nearly $20 \%$ (in terms of NISP) of identified fish remains at Lepenski Vir (Živaljević in prep.); it is also highly significant that some of the sculpted boulders from this site bore a resemblance to sturgeon features (Radovanovic 1997; Boric 2005). At the same time, the Lepenski Vir assemblage exhibited the greatest diversity of sturgeon species, including the remains of migratory beluga, Russian sturgeon, ship sturgeon, and stellate sturgeon, as well as those of freshwater sterlet (Acipenser ruthenus). The first species to enter the Danube is the large beluga, whose spring migration commences in late winter/early spring, reaching a peak in April and ending in late May/ June. Its autumn migration starts by late August, peaking in October/November. The Russian sturgeon starts its spring migration somewhat later than beluga (end of February/March), which peaks in April, and ends mid-May. The second migration starts in August/September, peaks in late September/mid-October and ends by mid-November. The ship sturgeon migrates in spring and autumn, with autumn populations remaining in the river until spawning, which takes place from March/April until June. The stellate sturgeon, the last species to enter the Danube, starts its spring migration in late April/ March, reaching a peak in May. Its autumn run begins by August and ends by September/mid-October (Tab. 4) (cf. Dinu 2010; Petrović 1998[1941]; Ristić 1977; Simonović 2001; Kottelat, Freyhof 2007; Bartosiewicz et al. 2008). Judging from interspecific variations in the migration start and peak dates of sturgeon species, migration pattern of vyrezub, as well as availability of freshwater fish, it might be hypothesised that fishing could have successfully taken place between late winter and late autumn, with particular intensity in spring and autumn. The remains of species active in winter (namely pike) are few, but the possibility of smoking and drying fish (the hearths in particular could have been used for this purpose) and storing it for winter months should not be excluded (cf. Bonsall 2008; Boric 2002; 2007). On the basis of fish remains from AMS dated contexts from Lepenski Vir (cf. Whittle et al. 2002; Bonsall et al. 1997; 2008; Borić, Dimitrijević 2009; Borić 2011), it was determined that fishing patterns remained relatively unchanged throughout the temporal sequence, i.e. that the distribution and proportion of species is more or less the same in both Mesolithic and Transformation phase contexts at the site ( $\check{Z} i$ valjevic in prep.).

Although bird remains have been uncovered at Lepenski Vir (Bökönyi 1969; 1970; 1972; Dimitrijević 2008 ), only a single bird bone found between the superimposed floors of Houses 20 and 33 (context dated to $6231-6056 \mathrm{cal} \mathrm{BC}$ at $95 \%$ probability (OxA15998) (Borić, Dimitrijević 2009) has been identified to the species level, originating from mallard (Borić, Dimitrijević 2006). As already noted, Anne Pike-Tay et alii (2004) state that the species is migratory, but used to breed in Hungary; whereas Javor Rašajski and Andrei Kiss (2004) note that it is

\footnotetext{
Fig. 7. Red deer left and right fragmented maxillae (LV 1296/1) found beneath the floor of House 19 at Lepenski Vir, originating from a 12-16 month old individual, captured between October and February. A fragment of vyrezub left pharyngeal bone with a row of 4 preserved teeth is attached to the right maxilla. a a fragment of the right maxilla with the two milk molars (D3 and

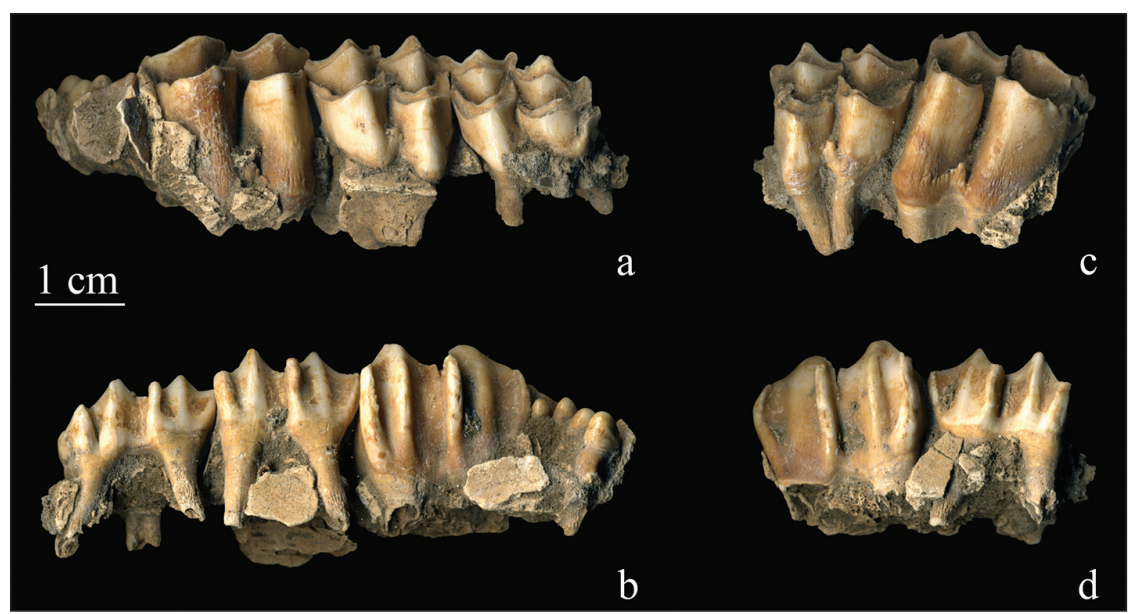
D4) and the first molar (M1) in eruption, lingual, attached vyrezub pharyngeal bone at the left; b same, buccal view, vyrezub teeth seen at the right side; c a fragment of the left maxilla with the last milk (D4) and the first permanent molar (M1), lingual; d same, buccal view.
} 
resident in Serbia, with a winter population increase due to migrant populations from the North of Europe.

\section{Padina}

The faunal assemblage from Padina, albeit entirely preserved, contained the fewest elements for a reliable estimate of occupational seasons (Tab. 3). Similarly to Lepenski Vir, this was mainly due to the hand-collection of animal bone, particularly biased towards fragile deciduous teeth and fish and bird remains. The majority of elements indicative of seasonality included shed and unshed red deer and roe deer antlers from both Mesolithic and Transformation phase contexts. These indicate kill seasons which occurred between September and February, determined on the basis of unshed red deer antlers, and May and October, on the basis of unshed roe deer antlers. The occurrence of shed antlers of red and roe deer indicate occupation in February-March and October-November, respectively, assuming they were collected shortly after shedding. The only mandible from a juvenile animal (PAD 28.8.69/1) originated from a roe deer, and was found in a Mesolithic occupational context (cf. Borić 2002.App. 3). Based on the presence of alveoli for D2-D3, D4 and a fragment of M1 (Fig. 8), it was determined that the animal was between four and eight months old (cf. Carter 2006), which suggested that it was captured between September and January.

In terms of fish remains, a specific feature of the faunal assemblage from Padina (even in comparison with other assemblages collected by hand) is the absolute predominance of catfish $(69.9 \%$ of all identified fish remains, and $77.1 \%$ of all fish remains identified to species) and least species diversity (Tab. 4) (Živaljević in prep.). Moreover, judging from the species distribution in AMS dated contexts (cf. Whittle et al. 2002; Borić, Miracle 2004; Borić 2011 ) and in contexts attributed to particular phases on the basis of stratigraphy (cf. Borić 2002.App. 3 ), it was determined that catfish remains become exceptionally abundant in the Transformation phase of the settlement. This could suggest that Padina established itself as a specialised centre oriented towards catching catfish during this time (Živaljević in prep.). Catfish is most successfully caught during its spawning season (from May to July) and during summer months, when it feeds most intensely ( $R i$ stić 1977; Simonović 2001; Kottelat, Freyhof 2007; Dinu 2010); however, given that the species is stationary, and hardly moves from its respective habitat (Ristic 1977), it can be hypothesised that it was available for most of the year. During cold seasons, however, catfish populations would decrease in number, as the species requires a water temperature of at least $18^{\circ} \mathrm{C}$ to reproduce ( $c f$. Bartosiewicz, Bonsall 2004.Tab. 7). As already suggested, the harsh winter seasons and periods when the river was covered in ice could be overcome by storing fish by smoking and drying (cf. Bonsall 2008; Borić 2002; 2007). In addition, the presence of anadromous sturgeons and vyrezub in the faunal assemblage suggests that freshwater fish exploitation at Padina was supplemented with fishing of seasonally available species, most notably in spring and autumn.

Bird remains are few in the faunal assemblage from Padina, which is suggestive of opportunistic exploitation; however, it is probably also a consequence of the sampling bias. The faunal assemblage consisted of the remains of six resident and three migratory species, some of them available in the Danube Gorges area for fairly short and seasonally limited periods of time (Tab. 5). Such is the case with the shellduck (Tadorna tadorna), which is present only in March and September-October, and white pelican, present in October-November. The black-throated diver (Gavia arctica) is present in the area from November to March (Rašajski, Kiss 2004), whereas in Central Europe it migrates in spring and autumn (Clason 1980). As already noted, the numbers of some of the resident populations (such as cormorant) increase in winter (cf. Clason 1980; Rašajski, Kiss 2004), which tentatively suggests they could have been exploited more frequently during this time.

\section{Discussion}

An important issue to be addressed here is whether permanent, year-round occupation can be distinguished from a series of repeated visits, of varying du-

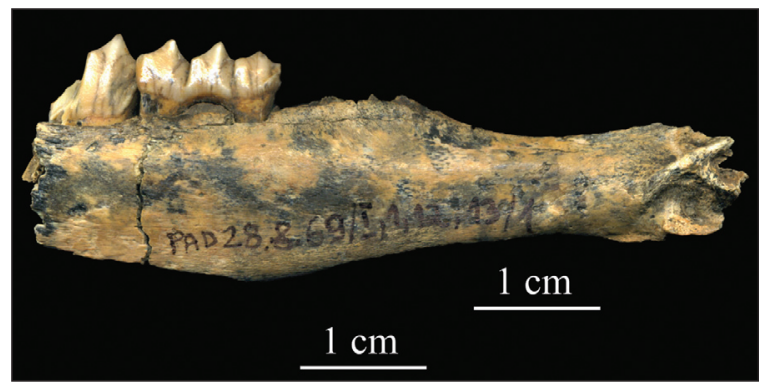

Fig. 8. Roe deer mandible with alveoli for milk molars (D2-D3), last milk molar (D4) and a fragment of the first permanent molar (PAD 28.8. 69/1) from a Mesolithic occupational context at Padina. The animal was between 4-8 months old, suggesting the capture occurred between September and January. 
ration, occurring at different seasons throughout the year? (cf. Whittle 2001; Conneller et al. 2012). This question, of course, remains very difficult to answer archaeologically. The patterns of food resource exploitation at Vlasac, corroborated with archaeological evidence, could be indications of the first scenario. The intensity of occupation in the Late Mesolithic phase (c. 7400-6300/6200 cal BC) is evidenced by several dug-out dwellings vaguely resembling the trapezoidal shape in plan, numerous stonelined hearths which were constructed in the open or were originally incorporated into dwellings that left no trace in the archaeological record, over hundred buried individuals and an enormous assemblage of tools and animal bones (cf. Srejović, Letica 1978; Nemeskéri 1978; Bökönyi 1978; Kozłowski, Koztowski 1982; Roksandić 1999; 2000; Borić et al. $2008 ; 2014)$. The faunal assemblage from the new 2006-2009 excavations of the site, which contained most elements suggestive of kill seasons (namely, erupting teeth of young animals), seems to indicate year-round occupation of the settlement. The exploitation patterns of red deer, the most important game animal, do not suggest any significant seasonal hiatus. Similarly, wild boar and roe deer hunting does not seem restricted to a particular season. Although most elements utilised in this study indicated a relatively broad time span, those that provided most precise and temporally restricted seasonal estimates point to hunting events which took place in all seasons. The fishing activity is indicative of spring and autumn months, judging from the presence of anadromous vyrezub and various sturgeon species, but fishing at other times was certainly possible, given that freshwater species represented in the sample would have been available for longer periods of time. Moreover, the fish could have been stored for winter by smoking and drying.

The hand-collected faunal assemblages from Lepenski Vir and Padina offered much less information for precise season determination, but tentative estimates do not point to a particular season of hunting. Furthermore, it can be suggested that resource exploitation patterns observed in the Late Mesolithic would have continued in the Transformation phase settlements (c. 6200-5900 cal BC). Several fairly precise season estimates obtained from specimens related to the construction and use of elaborate trapezoidalbase buildings at Lepenski Vir offer important insights into the life-cycles of particular buildings and, consequently, of the settlement as a whole. It is evident that some of dwellings were abandoned at different times of the year, while others remained in use; this feature is also suggested by the secondary position of some of the sculpted boulders. The significance of both hunting and fishing activities, which took place simultaneously for most of the year, is particularly illustrated by caches of mammal and fish bones stuck together and formed over a short period of time. It remains unclear to what extent the observed differences in preferences for fish species at Lepenski Vir and Padina would influence the nature of occupation of these sites; the latter oriented mostly towards catfish available for most of the year, and the former exhibiting greater species diversity and a significant amount of seasonably available sturgeon. Whereas the environment of Lepenski Vir and other sites would have provided substantial means for occupation lasting throughout the year, the exploitation of seasonally available fish could have been vital in (re)creating memories, events and specific temporal perspectives (Borić 2002).

\section{Conclusion}

This study offers additional data supporting the hypothesis that a significant degree of sedentism in the Danube Gorges existed already in the Late Mesolithic, prior to, and independently of, the adoption of animal and plant husbandry. Furthermore, recent studies of other Mesolithic contexts in Europe provide evidence of practices involving prolonged stays of human groups in certain locations; for example, the construction (involving a significant amount of time and effort) of substantial timber structures at Starr Car in Britain (Conneller et al. 2012) and largescale food storage and fish fermentation, implying a delayed-return subsistence strategy, at Norje-Sunnansund in Southern Scandinavia (Boethius 2016). Moreover, 'full-scale' sedentism commonly associated with food-producing communities could have also taken many different forms, including shifting cultivation crops or herds, and varying levels of mobility of individuals involved in such practices (Whittle 2001). These studies further problematise the relationship of sedentism and subsistence strategies, and add to our understanding of the complexity and diversity of forager and food-producing lifestyle and residential practices. In the Danube Gorges, evidence of Early Mesolithic occupation is relatively scarce, but the presence of several burials and stone constructions indicate a prolonged stay at riverine terraces. The higher resolution of dates, architectural features and artefacts related to the Late Mesolithic occupancy signal that by this time these locations were a home to fairly sedentary populations practicing an exclusively hunter-gatherer-fisher lifestyle. 
Their environment enabled the successful exploitation of wild game and fish for most, if not the whole, of the year.

Therefore, it can be argued that the construction of later, Mesolithic-Neolithic Transformation phase settlements at Lepenski Vir and Padina took place in a context where continuous human occupation and relationship with particular locales had been long established. It can also be hypothesised that these settlements, with more elaborate and permanent dwellings, would have followed similar patterns of occupation. Although the changes observed in the Transformation phase largely coincide with the emergence of the first food-producing communities in the region (and contacts with distant communities are evident already in the Late Mesolithic), certain (but not all) elements of Neolithic lifestyles were incorporated only after "they made sense in local terms" (Borić 2007). Most notably, animal husbandry had fairly little impact on the economy and lifestyle of Upper Gorge communities, with the remains of the first domesticates appearing only after most of the trapezoidal buildings had been abandoned.
It can be assumed then, that local traditions, established in a particular environment and involving locally available resources, merged with new cultural elements in the later parts of the sequence, played substantial roles in settlement practices in the Danube Gorges context.

\section{ACKNOWLEDGEMENTS}

This paper is a result of the Project "BIRTH: Births, mothers and babies: prehistoric fertility in the Balkans between 10 000-5000 BC", funded by the European Research Council (ERC) under the European Union's Horizon 2020 research and innovation programme (Grant Agreement No. 640 557). We thank Dušan Boric for the opportunity to study the faunal remains from the 2006-2009 excavations of Vlasac, Igor Askeyev for his help with determining some of the fish bones, and Mihael Budja for his kind invitation to participate in the 22nd Neolithic Seminar and for the superb organisation of the conference. We would also like to thank two anonymous reviewers for their insightful and constructive comments on earlier drafts of this paper.

\section{References}

Bartosiewicz L. 1989. Variability of tooth eruption in cattle. Acta Veterinaria Hungarica 37(4): 303-317.

Bartosiewicz L., Bonsall C. 2004. Prehistoric fishing along the Danube. Antaeus 27: 253-272.

Bartosiewicz L., Bonsall C. and Şişu V. 2008. Sturgeon fishing along the Middle and Lower Danube. In C. Bonsall, V. Boroneant and I. Radovanović (eds.), The Iron Gates in Prehistory. New perspectives. British Archaeological Reports IS 1893. Archaeopress. Oxford: 39-54.

Bartosiewicz L., Boroneant V., Bonsall C. and Stallibrass S. 1995. Schela Cladovei: a preliminary review of the prehistoric fauna. Mesolithic Miscellany 16(2): 2-19.

2001. New data on the prehistoric fauna of the Iron Gates: a case study from Schela Cladovei, Romania. In R. Kertész, J. Makkay (eds.), From the Mesolithic to the Neolithic. Proceedings of the International Archaeological Conference held in the Damjanich Museum of Szolnok, September 22-27, 1996. Archaeolingua. Budapest: 15-21.

Blaise E., Balasse M. 2011. Seasonality and season of birth of modern and late Neolithic sheep from south-eastern
France using tooth enamel $\delta^{180}$ analysis. Journal of Archaeological Science 38(11): 3085-3093.

Boethius A. 2016. Something rotten in Scandinavia: The world's earliest evidence of fermentation. Journal of Archaeological Science 66: 169-180.

Bökönyi S. 1969. Kičmenjaci (prethodni izveštaj). In D. Srejović (ed.), Lepenski Vir. Nova praistorijska kultura $u$ Podunavlju. Srpska književna zadruga. Beograd: 224-228.

1970. Animal Remains from Lepenski Vir. Science 167 (926): 1702-1704.

1972. The vertebrate fauna. In D. Srejović (ed.), $E u$ rope's first monumental sculpture: new discoveries at Lepenski Vir. Thames and Hudson. London: 186-189.

1978. The vertebrate fauna of Vlasac. In M. Garašanin (ed.), Vlasac. A Mesolithic Settlement in the Iron Gates. Volume II. Geology - Biology - Anthropology. Serbian Academy of Sciences and Arts Monographies. Belgrade: 35-65.

Bonsall C. 2008. The Mesolithic of the Iron Gates. In G. N. Bailey, P. Spikins (eds.), Mesolithic Europe. Cambridge University Press. Cambridge: 238-279. 
Bonsall C., Cook G. T., Hedges R. E. M., Higham T. F. G., Pickard C. and Radovanović I. 2004. Radiocarbon and stable isotope evidence of the dietary change from the Mesolithic to the Middle Ages in the Iron Gates: new results from Lepenski Vir. Radiocarbon 46: 293-300.

Bonsall C., Lennon R., McSweeney K., Stewart C., Harkness D., Boroneanţ V., Bartosiewicz L., Payton R. and Chapman J. 1997. Mesolithic and Early Neolithic in the Iron Gates: a palaeodietary perspective. Journal of European Archaeology 5(1): 50-92.

Bonsall C., Radovanović I., Roksandić M., Cook G., Higham T. and Pickard C. 2008. Dating burials and architecture at Lepenski Vir. In C. Bonsall, V. Boroneant and I. Radovanović (eds.), The Iron Gates in Prehistory. New perspectives. British Archaeological Reports IS 1893. Archaeopress. Oxford: $175-204$

Borić D. 2001. Mesolithic and early Neolithic hunters and fishers in the Danube Gorges: an analysis of archaeozoological data. In R. Kertész, J. Makkay (eds.), From the Mesolithic to the Neolithic. Proceedings of the International Archaeological Conference held in the Damjanich $\mathrm{Mu}-$ seum of Szolnok, September 22-27, 1996. Archaeolingua. Budapest: 101-124.

2002. Seasons, Life Cycles and Memory in the Danube Gorges, c. 10,000-5500 BC. Unpublished PhD thesis. University of Cambridge. Cambridge.

2005. Body metamorphosis and animality: volatile bodies and boulder artworks from Lepenski Vir. Cambridge Archaeological Journal 15(1): 35-69.

2006. New discoveries at the Mesolithic-Early Neolithic site of Vlasac: preliminary notes. Mesolithic Miscellany 18(1): 7-14.

2007. The House between Grand Narrative and Microhistory: a house society in the Balkans. In R. A. Beck (ed.), The Durable House. House Society Models in Archaeology. South Illinois University, Center for Archaeological Investigations, Occasional Paper No. 35. Carbondale: 97-129.

2010. Happy forgetting? Remembering and dismembering dead bodies at Vlasac. In D. Borić (ed.), Archaeology and Memory. Oxbow Books. Oxford: 48-67.

2011. Adaptations and transformations of the Danube Gorges foragers (c. 13,000-5500 BC): an overview. In R. Krauß (ed.), Beginnings - New Research in the Appearance of the Neolithic between Northwest Anatolia and the Carpathian Basin. Verlag Marie Leidorf Gmbh. Rahden: 157-203.

Borić D., Dimitrijević V. 2006. Continuity of foraging strategies in the Mesolithic-Neolithic transformations: dating faunal patterns at Lepenski Vir (Serbia). Atti della Società per la preistoria e protoistoria della regione FriuliVenezia Giulia XV (2004-05): 33-107.

2007. When did the 'Neolithic package' reach Lepenski Vir? Radiometric and faunal evidence. Documenta Praehistorica 34: 52-71.

2009. Apsolutna hronologija i stratigrafija Lepenskog Vira. Starinar LVII/2007: 9-55.

Borić D., French C. and Dimitrijević V. 2008. Vlasac revisited: formation processes, stratigraphy and dating. $D o-$ cumenta Praehistorica 35: 261-287.

Borić D., French C. A. I., Stefanović S., Dimitrijević V., Cristiani E., Gurova M., Antonović D., Allué E. and Filipović D. 2014. Late Mesolithic lifeways and deathways at Vlasac (Serbia). Journal of Field Archaeology 39(1): 4-31.

Borić D., Grupe G., Peters J. and Mikić Ž. 2004. Is the Mesolithic-Neolithic subsistence dichotomy real? New stable isotope evidence from the Danube Gorges. European Journal of Archaeology 7(3): 221-248.

Borić D., Miracle P. 2004. Mesolithic and Neolithic (dis) continuities in the Danube Gorges: new AMS dates from Padina and Hajdučka Vodenica (Serbia). Oxford Journal of Archaeology 23(4): 341-371.

Borić D., Price T. D. 2013. Strontium isotopes document greater human mobility at the start of the Balkan Neolithic. Proceedings of the National Academy of Sciences of USA 110(9): 3298-3303.

Brinkhuizen D. C. 1986. Features observed on the skeletons of some recent European Acipenseridae: their importance for the study of excavated remains of sturgeon. In D. C. Brinkhuizen, A. T. Clason (eds.), Fish and Archaeology. Studies in osteometry, taphonomy, seasonality and fishing methods. British Archaeology Reports IS 294. Archaeopress. Oxford: 18-33.

Brown W. A. B., Chapman N. G. 1991. The dentition of red deer (Cervus elaphus): a scoring scheme to assess age from wear of the permanent molariform teeth. Journal of Zoology 224(4): 519-536.

Bull G., Payne S. 1982. Tooth eruption and epiphyseal fusion in pigs and wild boar. In B. Wilson, C. Grigson and S. Payne (eds.), Ageing and sexing animal bones from archaeological sites. British Archaeology Reports IS 109. Archaeopress. Oxford: 55-71.

Carter R. J. 2006. A method to estimate the ages at death of red deer (Cervus elaphus) and roe deer (Capreolus capreolus) from developing mandibular dentition and its application to Mesolithic NW Europe. In D. Ruscillo (ed.), Recent advances in ageing and sexing animal bones. 
Proceedings of the 9 $9^{\text {th }}$ ICAZ conference. Oxbow Books. Oxford: 40-61.

Carter R. J., Magnell 0. 2007. Age estimation of wild boar based on molariform mandibular tooth development and its application to seasonality at the Mesolithic site of Ringkloster, Denmark. In U. Albarella, K. Dobney, A. Ervynck and P. Rowley-Konwy (eds.), Pigs and humans: 10,000 years of interaction. Oxford University Press. Oxford: 197-217.

Chapman J. 1993. Social power in the Iron Gates Mesolithic. In J. Chapman, M. P. Dolukhanov (eds.), Cultural Transformations and Interactions in Eastern Europe. Aldershot. Avebury: 71-121.

Clason A. T. 1980. Padina and Starčevo: game, fish and cattle. Palaeohistoria 22: 141-173.

Clements J. F., Schulenberg T. S., Iliff M. J., Roberson D., Fredericks T. A., Sullivan B. L. and Wood C. L. 2014. The eBird/Clements checklist of birds of the world. Version 6.9. http://www.birds.cornell.edu/clementschecklist/down load/

Conneller C., Milner N., Taylor B. and Taylor M. 2012. Substantial settlement in the European Early Mesolithic: new research at Star Carr. Antiquity 86(2012): 10041020.

Cristiani E., Borić D. 2012. 8500-year-old Late Mesolithic garment embroidery from Vlasac (Serbia): technological, use-wear and residue analyses. Journal of Archaeological Science 39(11): 3450-3469.

Cristiani E., Živaljević I. and Borić D. 2014. Residue analysis and ornament suspension techniques in prehistory: Cyprinid pharyngeal teeth beads from Late Mesolithic burials at Vlasac (Serbia). Journal of Archaeological Science 46: 292-310.

Dimitrijević V. 2000. The Lepenski Vir fauna: bones in houses and between houses. Documenta Praehistorica 27: 101-117.

2008. Lepenski Vir animal bones: what was left in the houses? In C. Bonsall, V. Boroneanț and I. Radovanović (eds.), The Iron Gates in Prehistory. New perspectives. British Archaeological Reports IS 1893. Archaeopress. Oxford: 117-130.

Dimitrijević V., Vuković S. 2015. Was the dog locally domesticated in the Danube Gorges? Morphometric study of dog cranial remains from four Mesolithic-Early Neolithic archaeological sites by comparison with contemporary wolves. International Journal of Osteoarchaeology 25 (1): $1-30$.
Dimitrijević V., Živaljević I. and Blažić S. Submitted. Faunal remains. In D. Borić (ed.), Vlasac: a Mesolithic site in the Danube Gorges revisited.

Dinu A. 2010. Mesolithic fish and fishermen of the lower Danube (Iron Gates). Documenta Praehistorica 37: 299310.

Garašanin M., Radovanović I. 2001. A pot in House 54 at Lepenski Vir I. Antiquity 75: 118-125.

Grubač B., Milovanović Z. and Šekler M. 2013. Ptice Đerdapa. Princip pres: Zavod za zaštitu prirode Srbije - Nacionalni park "Đerdap" - Veterinarski specijalistički institut "Kraljevo". Beograd - Donji Milanovac - Kraljevo.

Grupa autora 1991. Velika ilustrovana enciklopedija lovstva. DIP, građevinska knjiga - DNEVNIK. Beograd - Novi Sad.

Grupe G., Mikić Ž., Peters J. and Manhart H. 2003. Vertebrate food webs and subsistance strategies of Meso and Neolithic populations of Central Europe. In G. Gruppe, J. Peters (eds.), Documenta Archaeobiologiae 1. Jahrbuch der Staatssammlung für Anthropologie und Paläoanatomie. Verlag Marie Leidorf, Rahden/Westf. München: 193-213.

Habermehl K.-H. 1985. Altersbestimmung bei Wild-und Pelztieren. Verlag Paul Parey. Hamburg, Berlin.

Jovanović B. 2008. Micro-regions of the Lepenski Vir culture: Padina in the Upper Gorge and Hajdučka Vodenica in the Lower Gorge of the Danube. Documenta Praehistorica 35: 289-324.

Kottelat M., Freyhof J. 2007. Handbook of European Freshwater Fishes. Publications Kottelat. Cornol.

Kozłowski J. K., Kozłowski S. K. 1982. Lithic industries from the multi-layered Mesolithic site Vlasac, in Yugoslavia. In J. K. Kozłowski (ed.), Origin of the Chipped Stone Industries of the Early Farming Cultures in the Balkans. Prace archeologiczne 33. Panstwowe Wydawnictwo Naukowe. Warszawa-Krakow: 11-109.

Nehlich 0., Borić D., Stefanović S. and Richards M. P. 2010. Sulphur isotope evidence for freshwater fish consumption: a case study from the Danube Gorges, SE Europe. Journal of Archaeological Science 37: 1131-1139.

Nemeskéri J. 1978. Demographic structure of the Vlasac Epipalaeolithic population. In M. Garašanin (ed.), Vlasac. A Mesolithic Settlement in the Iron Gates. Volume II. Geology - Biology - Anthropology. Serbian Academy of Sciences and Arts Monographies. Belgrade: 97-133.

Petrović M. 1998. [orig. 1941]. Đerdapski ribolovi u prošlosti i sadašnjosti. In D. Trifunović (ed.), Ribarstvo. Sa- 
brana dela Mihaila Petrovića. Zavod za udžbenike i nastavna sredstva. Beograd: 175-270.

Pike-Tay A., Bartosiewicz L., Gál E. and Whittle A. 2004. Body part representation and seasonality: sheep/goat, bird and fish remains from Early Neolithic Ecsegfalva 23, SE Hungary. Journal of Taphonomy 2(4): 221-246.

Puzović S. 2000. Atlas ptica grablivica Srbije - mape rasprostranjenosti i procene brojnosti 1977-1996. Zavod za zaštitu prirode Srbije. Beograd.

Radovanović I. 1996. The Iron Gates Mesolithic. International Monographs in Prehistory. Ann Arbor.

1997. The Lepenski Vir culture: a contri-bution to interpretation of its ideological aspects. In D. Srejović, M. Lazić (eds.), Antidoron Dragoslavo Srejović completis LXV annis ab amicis, collegis, discipulis oblatum. Centar za arheološka istraživanja. Beograd: 87-93.

Radovanović I., Voytek B. 1997. Hunters, fishers or farmers: sedentism, subsistence and social complexity in the Đerdap Mesolithic. In A. van Gijn, C. Bakels and M. Zvelebil (eds.), Ideology and Social Structure of Stone Age Communities in Europe. Analecta Praehistorica Leidensia 29: 19-31.

Rašajski J., Kiss A. 2004. Ptice Banata. Gradski muzej Vršac. Vršac.

Ristić M. 1977. Ribe i ribolov u slatkim vodama. Nolit. Beograd.

Roksandić M. 1999. Transition from Mesolithic to Neolithic in the Iron Gates Gorge: Physical Anthropology Perspective. Unpublished PhD thesis. Department of Anthropology. Simon Fraser University. Vancouver.

Roksandić M. 2000. Between foragers and farmers in the Iron Gates Gorge: physical anthropology perspective. Đerdap population in transition from Mesolithic to Neolithic. Documenta Praehistorica 27: 1-100.

Schmid E. 1972. Atlas of Animal Bones: For Prehistorians, Archaeologists and Quaternary Geologists. Elsevier Publishing Company. Amsterdam, London, New York.
Simonović P. 2001. Ribe Srbije. NNK Internacional. Biološki fakultet Univerziteta u Beogradu. Zavod za zaštitu prirode Srbije. Beograd.

Srejović D. 1969. Lepenski Vir: Nova praistorijska kultura u Podunavlju. Srpska Književna Zadruga. Beograd.

1972. Europe's first monumental sculpture: new discoveries at Lepenski Vir. Thames and Hudson. London.

Srejović D., Letica, Z. 1978. Vlasac. Mezolitsko naselje u Đerdapu (I arheologija). Srpska akademija nauka i umetnosti. Beograd.

Takács I., Bartosiewicz L. 1998. Data on the history of fish exploitation in Hungary. Internet Archaeology 4. http:// intarch.ac.uk/journal/issue $4 /$ takacs_index.html

Voytek B. A., Tringham R. 1989. Rethinking the Mesolithic: the case of South-East Europe. In C. Bonsall (ed.) The Mesolithic in Europe. Papers Presented at the Third International Symposium Edinburgh 1985. John Donald Publishers Ltd. Edinburgh: 492-499.

Wheeler A., Jones A. K. G. 1989. Fishes. Cambridge Manuals in Archaeology. Cambridge University Press. Cambridge.

Whittle A. 2001. From mobility to sedentism: change by degrees. In R. Kertész, J. Makkay (eds.), From the Mesolithic to the Neolithic. Proceedings of the International Archaeological Conference held in the Damjanich Museum of Szolnok, September 22-27, 1996. Archaeolingua. Budapest: 447-461.

Whittle A., Bartosiewicz L., Borić D., Pettitt P. and Richards M. 2002. In the beginning: new radiocarbon dates for the Early Neolithic in Northern Serbia and South-East Hungary. Antaeus 25(2002): 63-117.

Živaljević I. in prep. Ribolov na Đerdapu u ranom holocenu (10. - 6. milenijum pre n. e.). Unpublished $\mathrm{PhD}$ thesis. Department of Archaeology. Faculty of Philosophy. University of Belgrade. Belgrade.

Živaljević I., Popović D., Snoj A. and Marić S. submitted. Ancient DNA analysis of cyprinid remains from the Mesolithic-Neolithic Danube Gorges reveals an extirpated fish species Rutilus frisii (Nordmann, 1840). 


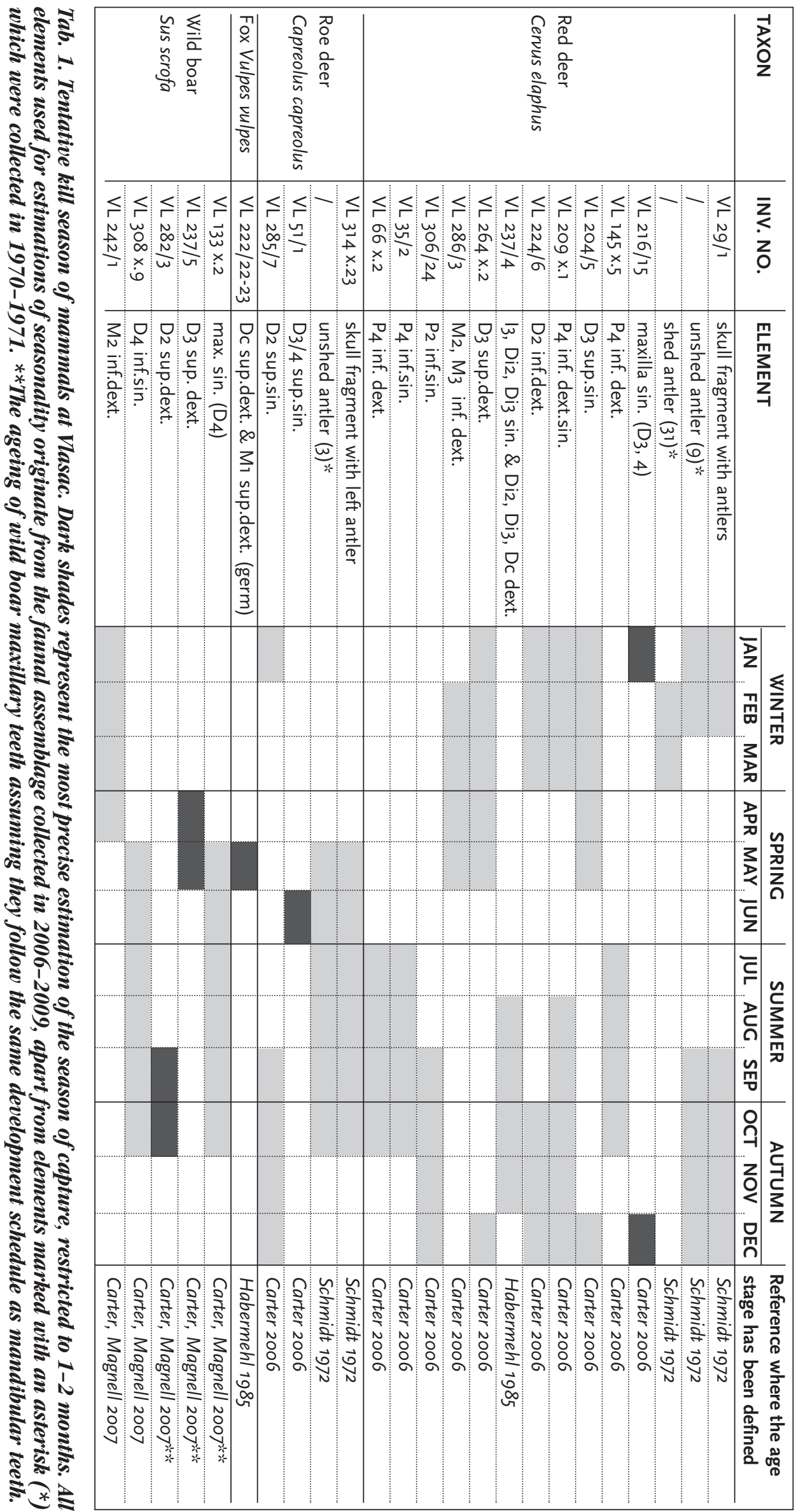



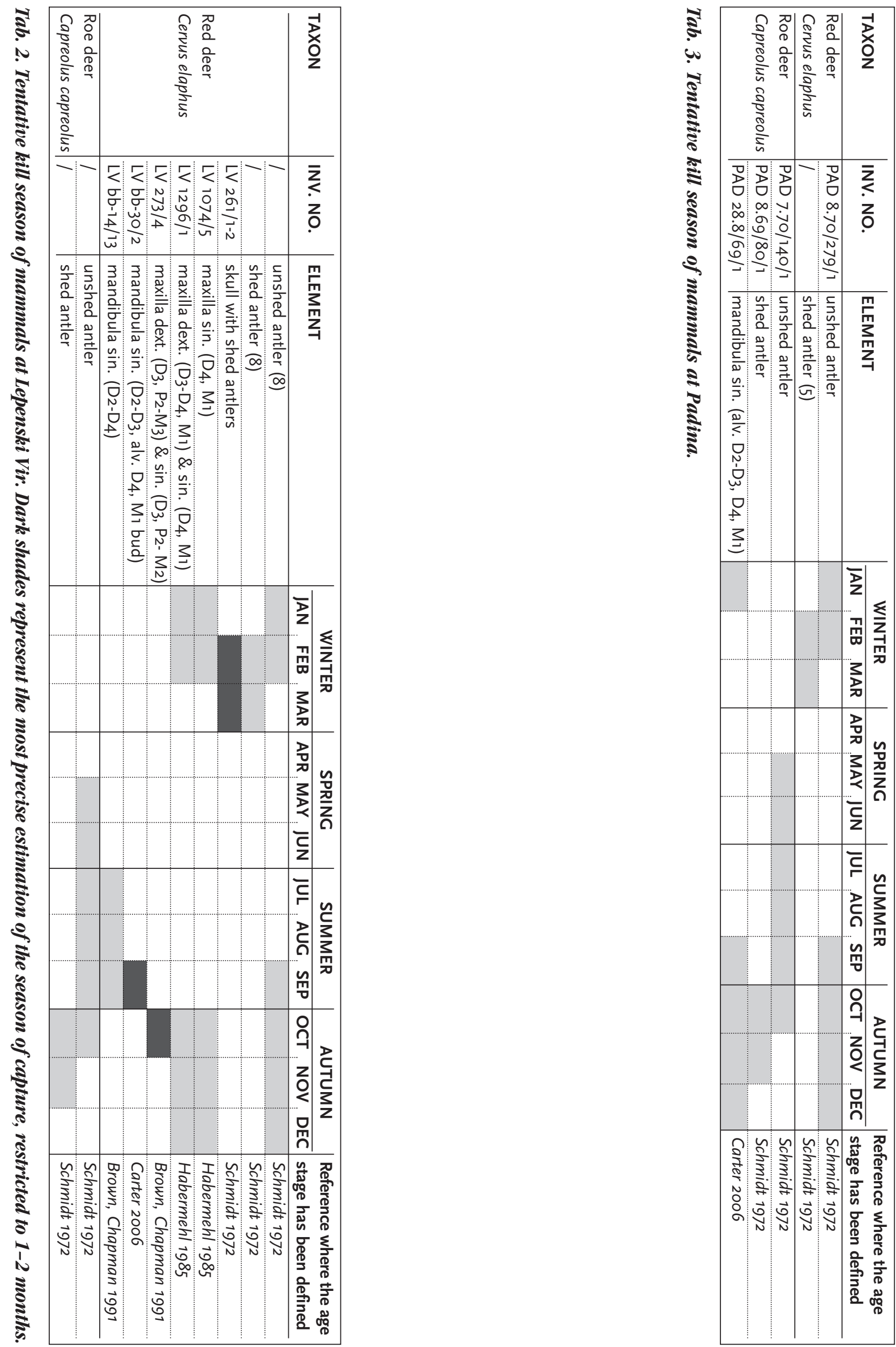


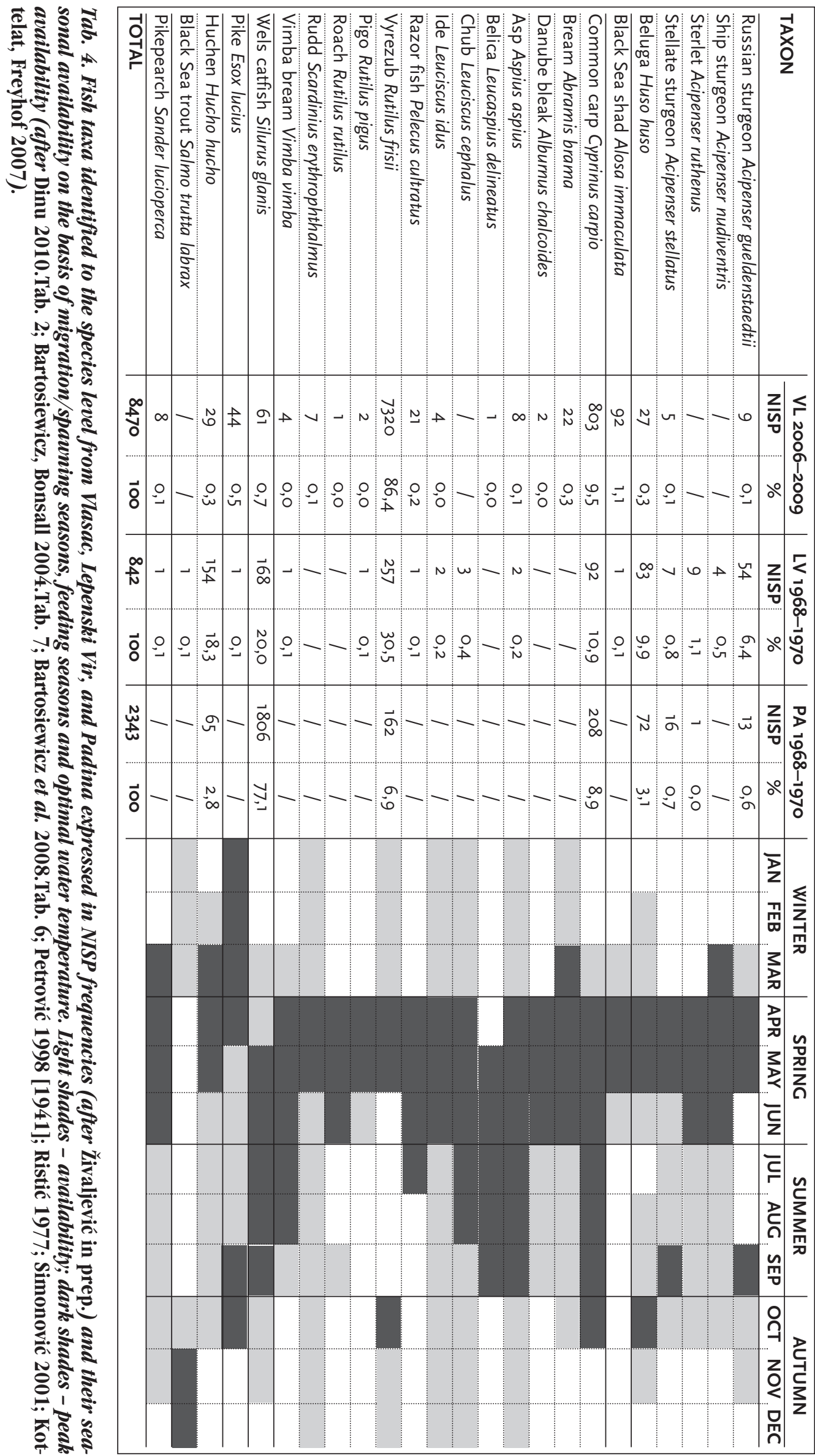




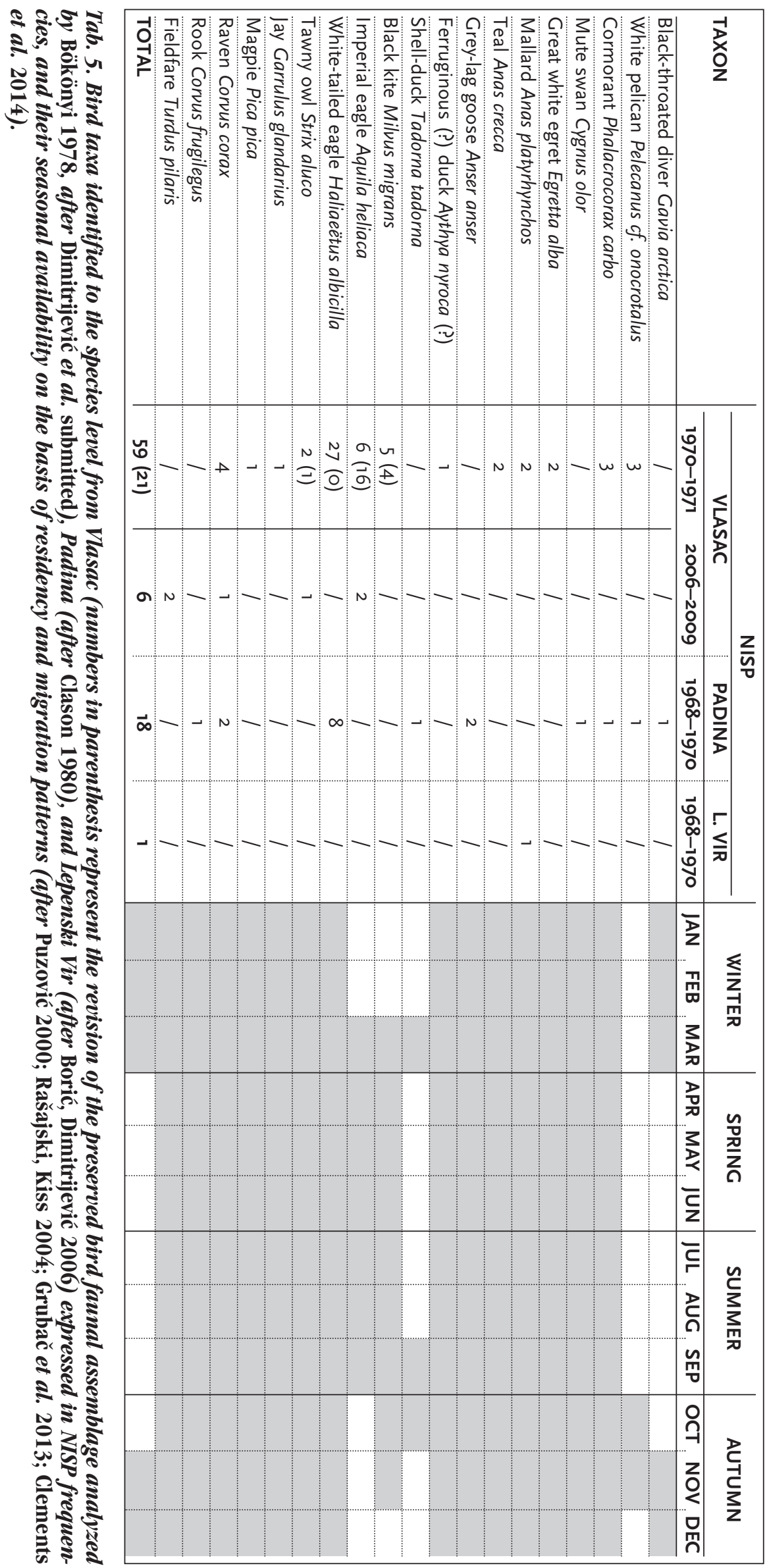

